InOedia $\quad \begin{aligned} & \text { InMedia } \\ & \text { The French Journal of Media Studies }\end{aligned}$

$2 \mid 2012$

Performing/Representing Male Bonds

\title{
Internet Studies in Europe
}

Symposium on Internet and Society, 25-28 October 2011, Humboldt

University, Berlin

ICTs and Society Conference, 2-4 May 2012, Uppsala University, Uppsala

Mathieu O'Neil

\section{OpenEdition}

\section{Journals}

Electronic version

URL: http://journals.openedition.org/inmedia/489

DOI: 10.4000/inmedia.489

ISSN: 2259-4728

\section{Publisher}

Center for Research on the English-Speaking World (CREW)

Electronic reference

Mathieu O'Neil, «Internet Studies in Europe », InMedia [Online], 2 | 2012, Online since 15 January 2013, connection on 08 September 2020. URL : http://journals.openedition.org/inmedia/489 ; DOI : https:// doi.org/10.4000/inmedia.489

This text was automatically generated on 8 September 2020

(c) InMedia 


\section{Internet Studies in Europe}

Symposium on Internet and Society, 25-28 October 2011, Humboldt

University, Berlin

ICTs and Society Conference, 2-4 May 2012, Uppsala University, Uppsala

\section{Mathieu O'Neil}

\section{EDITOR'S NOTE}

The First Berlin Symposium on Internet and Society - Exploring the Digital Future was organised by Ingolf Pernice, Jeanette Hofmann, Thomas Schildhauer and Wolfgang Schulz. See http://berlinsymposium.org/.

The Fourth ICTs and Society Conference, Critique, Democracy and Philosophy in $21^{\text {st }}$ Century Information Society - Towards Critical Theories of Social Media was organised by Christian Fuchs and Marisol Sandoval. See http://www.icts-and-society.net/events/ uppsala2012/.

1 Internet studies have historically developed in the United States. The Oxford Internet Institute (OII), launched in 2001, was the first European Internet research department rather than a research centre or programme in a disciplinary department, the OII was able to offer degrees. To some extent, OII has managed to create an analytical perspective distinct from the cyber-law focus of major US research centres such as Harvard's Berkman Centre for Internet and Society and the Annenberg School for Communication, though it does share the US focus on public policy and e-social science. It was therefore of great interest to Internet scholars that two landmark conferences were to be held on the European continent: the First Berlin Symposium on Internet and Society was convened to launch the Berlin Institute for Internet and Society; whilst the Fourth ICTs \& Society conference was to be held at Uppsala University in Sweden. Since I had the opportunity to attend both events, I will discuss them in comparative fashion in terms of background, organisation, and ideology. 


\section{Background}

The Berlin Institute was launched with significant financial support from Google, because, as Google's Europe Blog put it:

[T] Ine Internet is changing society. And it's also true that society is changing the Internet, through the choices we all make on the web every day. For Google, the point at which the Internet and society intersect is fascinating. Seeing different perspectives and understanding cultural nuances is critical to how we develop our services. $^{1}$

Skeptics have conjectured that launching the Institute is in fact a ploy to 'win over' Europeans worried about the firm's power and the threat it poses to data protection. Whatever the case may be, it does not detract from the assembled research capacity. Four German institutions have each delegated a Director to the Institute, reflecting a wide diversity of outlooks: Professor Ingolf Pernice (Humboldt University) will specialise in Internet and constitutional law; Dr Jeanette Hofmann (Social Science Research Center Berlin) brings her Internet governance and regulation expertise; Professor Thomas Schildhauer (University of the Arts) his interest in Internet-based innovation and the economy; and Dr Wolfgang Schulz (Hamburg Hans Bredow Institute) his focus on media law.

The ICTs \& Society network is an open and informal project, which anyone can join. It was initially the brainchild of Professors Wolfgang Hofkirchner and Christian Fuchs in Salzburg. After working in his native Austria, Fuchs was appointed in 2011 Chair in Media and Communication Studies of the Department of Informatics and Media Studies at Uppsala. One of Fuchs' central concerns is to counter what he views as the a-critical and non-normative perspective of Manuel Castells (arguably the best-known theoretician of the information society) by developing "Critical Internet Studies", chiefly through the application of Critical Theory concepts to Internet studies. Typical questions might include: "Is digital labour productive or unproductive labour? Does it involve exploitation and/or alienation and/or objectification and/or reification? What is the relationship between production and consumption and between commodification and ideology in the realm of digital media today? Is play labour exploited even if it is fun?"2 Professor Fuchs is also the editor of Triplec (Cognition, Communication, Cooperation), an "Open Access Journal for a Global Sustainable Information Society". Earlier ICTs \& Society meetings were on a smaller scale and took place in Salzburg, Trento and Barcelona.

\section{Organisation}

5 In Berlin, after the opening ceremony and reception at Humboldt University on Unter den Linden, the sessions and keynotes took place at the Nhow hotel - an über-trendy spot where every surface was either mauve or pink, the lifts exploded in bright psychedelic yellow, and the lobby and bar made one feel as if one was inside a lavalamp. The terrace overlooked the Spree and what appeared to be artistically decorated blocks of the Berlin Wall. The traditional part of the Symposium took place on the ground floor, in a modular space that could be divided into three large rooms. The lunches, Open Science Forum and evening revelries occurred in an upstairs area, above the art gallery, which had a bar and an unfinished, rough, loft-type atmosphere. 
Google's presence meant the Symposium was well endowed, and the organisers could experiment with all kinds of ideas to make it more interactive. The website enabled all participants and attendees to list their identities and interests. Upon registration, everyone received a bag comprising the usual conference kit (the program, a nice booklet to write in, and since we were at the Nhow the gift pen was pink) as well as a mysterious flat metal object and a series of cards with attendees' names and those geometric black and white squares that appear on every ad and artwork these days. The mysterious object turned out to be an ultra-flat USB stick with all the conference papers and research questions in PDF format (all the papers were of impressive quality). As for the flashcodes: when you wanted to say something in a session, you were supposed to alert helpers, who would scan your card with their phone so that when it was your turn to speak, your name, affiliation and interests were projected onto a screen. A different screen featured a blow-by-blow collaboratively produced summary of interventions. In addition, every session comprised an artist who drew in real time a large illustration of what people were talking about. People were also encouraged to write ideas on cards and panels outside the sessions but I did not notice that these were used much.

7 In the lead-up to the Berlin symposium research questions were collectively developed, whilst keynote abstracts were posted to the ICTs \& Society email list and generated quite lively exchanges. This was intended to determine some of the dominant themes to be discussed. Uppsala is a small university town, sometimes described as the 'Swedish Oxbridge'. The conference was held in the Ekonomikum, a maze-like structure with nicely high wooden desks in the amphitheatre, definitely a plus for tall folks. In general the ICTs \& Society conference felt more traditional, with efficient time keeping (15 minutes for presenting, five minutes for discussion) which was scrupulously enforced by all the session managers. Whereas Berlin ended with a sparsely attended DJ party, Uppsala wrapped proceedings up with a banquet where guests were issued a booklet featuring lyrics to drinking songs. They also brought in a choir to sing a few songs, which was nice.

\section{Ideology}

8 The Berlin Symposium gathered worldwide experts on Internet issues, so there was a great diversity of outlooks in attendance, from business types, to researchers (including representatives from the Berkman Center and the OII), to free software and 'smart cities' activists. ${ }^{3}$ In her opening remarks, Director Jeanette Hofmann framed her research objectives around the notion of the public domain, emphasising concerns such as determining which public domain areas transcend specific fields of operation, the impact of technological and regulatory changes to the public domain on democratic dialogue, and the consequences of interactions between different types of public domain regulation over time. The first two days followed the traditional conference formats - smaller workshop sessions alternating with keynote plenaries. Plenaries included homilies to the Internet's potential to develop technological innovation (for example "Internet as a Motor for Societal Innovation", by Oliver Gassmann of the University of St. Gallen) whilst others dealt with its potential to liberate the oppressed of the earth from the shackles of tyranny (though acknowledging the challenges posed by corporations to individual liberty) as for example "Consent of the Networked: The 
Future of Freedom in the Internet Age" by Rebecca MacKinnon of the New America Foundation. In terms of the workshop sessions, I appreciated the presentation by Malte Ziewitz (OII) entitled "Can Crowd Wisdom Solve Regulatory Problems?". Ziewitz presented an overview of the notion of crowdsourcing by tracing its historical antecedents, providing examples of contemporary applications (such as the US Patent Office's Peer-to-Patent, the New Zealand Policing Act wiki, and web-based patient feedback for the NHS in the UK) and the challenges posed by the rise of lay expertise and feedback to traditional regulatory agencies.

9 All the workshop papers are available as individual files on the conference website. There was a definite buzz in Berlin as Google's backing imbued the proceedings with a certain weight - the underlying message was this was not just another conference, but the start of something significant. The significance of the event was undeniable, as so many people were gathered in one place, but its meaning was harder to fathom. The numerous quality contributions in the realm of political science, communications and law, with their concern for developing the public sphere, mapping online governance, increasing citizen participation, and the like, seemed to sit a little uneasily with the management focus on capturing crowd-sourced innovation for profit. It sometimes felt as if two different conferences were happening in the same space.

The last day was an Open Science Forum which would, to quote the program, provide an "innovative platform" for academics and "stakeholders from industry, politics and various civil society interest groups to discuss and work on the real world problems of the information society". Participants were arranged in small teams and encouraged to take part in "trans-disciplinary working sessions". Google's Damon Horowitz, who, aside from his Doctorate in philosophy from Stanford, holds a degree in artificial intelligence from MIT, delivered that day's morning keynote on "Humanism and Technology". He urged researchers to engage with Google to make it a better company, but failed to address the concerns raised by the firm's ever-growing accumulation of online and offline individual and corporate data. Other Google employees were in attendance at the Symposium. When I wondered aloud in a session whether Google might be the first transnational corporation whose business model was based on the disregard for copyright (as a recent example, Google only modified in 2012 their search algorithm to index non-copyrighted content lower than copyrighted content in their search results), a Google employee not only expressed vehement disagreement with my statement, but asked that it be "struck from the record". I do not know whether this happened or not, but it struck me as a rather heavy-handed way of dealing with ideas one disagrees with. Since this happened at the end of a session, I did not notice any other reactions.

In contrast to the vision of the Internet as an essentially positive or even liberating phenomenon, at the ICTs \& Society conference in Uppsala the notion of the participatory web was described as an illusory 'ideology' and the global network, more often than not, portrayed in terms of exploitation of free labour and crowdsourcing of surveillance. Interestingly, there was a significant Canadian contingent in Uppsala. This brings to mind the fact that many Canadian communications scholars have adopted a far more critical attitude than their US counterparts - see for example Vincent Mosco (Queen's University), Andrew Feenberg (Simon Fraser University) and Nick DyerWitherford (University of Western Ontario), who were all plenary speakers. Mosco opened the conference with a speech entitled "Marx is Back, but Will Knowledge 
Workers of the World Unite? On the Critical Study of Labour, Media, and Communication Today", where he advocated focusing on strategies and tactics for activism. Feenberg was the final speaker, and his talk, "Great Refusal and Long March: How to Use Critical Theory to Think About the Internet", conceptualised the Internet as a site of struggle between the consumption model and the community model. Following Marcuse, Feenberg argued for the need to enter dominant institutions and contest them from within. Dyer-Witherford's talk, "Cybermarxism Today: Cycles and Circuits of Struggle in 21st Century Capitalism", tracked a new class composition, the Weltgesamtarbeiter or 'global worker', a collective labour organised not along the assembly line of the factory, but along planet-spanning supply chains. This talk was very well received by the audience, though a case could be made that Occupy Wall Street (and other Western anti-austerity struggles), the Arab Spring, Chinese migrant worker protests and peasant struggles in Latin America are parallel, rather than interconnected events.

Sessions were entitled "Towards a Critical Theory of Social Media: The Dialectics of Empowerment and Disempowerment" and "Surveillance 2.0? Commodification, Policification, and Discrimination in the 'Surveillance Society". A conference focus was indeed surveillance, and a notable plenary presentation was by a specialist in the field, Mark Andrejevic (University of Queensland), whose talk, "Social Media: Surveillance and Exploitation 2.0", described "the most comprehensive system for mass monitoring in human history", based on "digital enclosure", whereby users are separated from the ownership of their data in order for a process of privatization to occur. In my view, the focus on Facebook as a form of surveillance and exploitation of free digital labour possibly overly dominated the conference (to be fair, a session was devoted to social movements and the Arab Spring). The final wrap-up plenary session was led by Professor Fuchs, the microphone wielder, who seemed to pick with a little too much care who would be allowed to speak. I will therefore take advantage of this opportunity to suggest that more attention could have been given to positive developments in the information society, such as the growth of the physical and digital commons, of open data and open access, and of 'collaborative' or 'peer' production such as free software and Wikipedia, all of which represent - granted, fragile and contradictory alternatives to the dominant system.

\section{The Future}

These events face opposed challenges: whilst the Berlin Institute for Internet and Society has a strong potential for development, because of Germany's position at the heart of Europe and because of Google's support, it also needs to create an identity from quite distinct research traditions, as well as secure funding beyond Google's three-year grant. In contrast, the ICTs \& Society research network has a clear identity; its challenge lies in forging alliances with other research streams, so as to avoid 'preaching to the choir', and finding itself overly isolated.

14 The risks of partitioning can be observed at the national level as well. Since they were held in Germany and Sweden both events obviously had a strong local flavour, with many researchers from both countries presenting papers. However, all the talks were given in English. As far as I am aware, apart from myself and a PhD student in Uppsala, there were no French researchers presenting papers at either event (there was at least 
another French academic present in Berlin). This confirms the observation that linguistic isolation is having a deleterious effect on French-language research, which is effectively cut off from global knowledge networks.

\section{NOTES}

1. Max Senges, "Research Institute for Internet and Society in Berlin", Google Europe Blog, July 11, 2012. http://googlepolicyeurope.blogspot.fr/2011/07/research-institute-for-internetand.html

$<$ accessed on September 4, 2012>

2. Christian Fuchs, "New Marxian Times! Reflections on the Fourth ICTs and Society-Conference: Critique, Democracy, and Philosophy in 21st Century Information Society. Towards Critical Theories of Social Media", TripleC 101 (2012): 114-21.

3. 'Smart cities' refers to the use of ICTs to make urban environments more socially and environmentally sustainable (in the activist variant) or more competitive and attractive to investors (in the business-oriented understanding).

\section{AUTHOR}

\section{MATHIEU O'NEIL}

Université Paris Sorbonne - Paris 4 